Walter E. Block

ORCID: 0000-0003-2215-4791

Loyola University New Orleans

wblock@loyno.edu

\title{
Human shields, missiles, negative homesteading and libertarianism*
}

Date of submission: 11.01.2017; date of acceptance: 28.02.2019

JEL Classification: K00, K11, K14, K15, K19

Keywords: human shields, missiles, negative homesteading, libertarianism, self-defense, trolley

\begin{abstract}
Human shields, missiles, negative homesteading and libertarianism

When a bad guy throws one innocent person against another, or uses one as a body shield so as to facilitate murdering the other, or is in the process of bashing in the heads of two such people, what are the rights and responsibilities of each of these latter two victimized parties vis a vis each other? The concept of negative homesteading is introduced in an attempt to shed light on these legal puzzles.
\end{abstract}

\section{Introduction}

The present paper is an attempt to wrestle with issues of force used against innocent parties. In section 2 we introduce the problem. Section 3 is devoted to a discussion of our proposed solution to these quandaries: negative homesteading. The burden of section 4 is to apply this insight to the analysis that several other authors have applied to such issues. We conclude in section 5.

* The author would like to thank several people for help in the writing of this article: David Gordon, Guido Hülsmann, Michael Munger. The author alone, of course, is fully responsible for all errors. 


\section{The problem}

Suppose $\mathrm{B}$ were to use $\mathrm{C}$ as a body shield in order to shoot $\mathrm{A}$ with guaranteed safety. That is, B hides behind C; C completely covers B, such that the only way that A can let loose a bullet at $\mathrm{B}$, in self-defense, is to go right through the completely innocent C. In order to defend himself against B, A must kill both B and C. B is threatening murder against $\mathrm{A}$, and is thus the only really guilty party, so far, of the piece; he is the perpetrator. $\mathrm{C}$ and $\mathrm{A}$ are completely innocent of any wrongdoing. All three of them, A, B, and C are armed with pistols, only for some reason or other C's only option is to fire at $\mathrm{A}$; he is precluded from turning around and aiming at $\mathrm{B}$. $\mathrm{B}$ controls $\mathrm{C}$ to the extent that $\mathrm{C}$ cannot turn around and shoot $\mathrm{B}$, nor can he escape from the clutches of B.

One question that immediately arises in this tableau is: who may properly shoot whom? In the wider sense of libertarian law, which would be a justified shoot? ${ }^{1}$ We already know that it would not be proper, from a libertarian perspective, for B to shoot A, or for that matter, to in effect kidnap C and use him as a body shield, in our present scenario. The interesting question of course is, given two innocent people, $\mathrm{C}$ and $\mathrm{A}$, which of them is entitled to shoot the other? Or is it both, or neither?

Before venturing into this thicket, let us first attempt to justify this entire exercise. One might think that no such justification would be needed. After all, what with Israeli accusations that Hezbollah is using civilians as human shields, by locating rocket launching apparatus in residential areas, such issues are in the popular news. Nevertheless, there is a body of thought according to which it is mere armchair philosophizing or "constructivism" (Hayek, 1973-1979; Diamond, 1980) to attempt to shed light on such problems. Better, according to this line of reasoning, to leave such questions to judges, or juries, or to the free enterprise system in general.

I must say that I am very much out of sympathy with such sentiments. I bow to no one in my adherence to market processes, and competition between private firms in the law and order business. However, it seems to me to be almost a dereliction of duty to not even attempt to apply the libertarian perspective to such issues. If we fail to shed light on this puzzle, we can always resort to Hayek's famous aphorism "by human action but not through human design".

Here is another objection to the entire undertaking: private property rights will determine such issues. We therefore need not resort to anything as arcane as legislative or judge-made law, let alone libertarian theory. Each man is a king in his own castle. These altercations, where $\mathrm{B}$ uses $\mathrm{C}$ as a shield to help him murder

${ }^{1}$ In the narrower sense of libertarian law, strictly speaking, we cannot address the question of who may properly shoot whom. We can only confront the issue of, if someone shoots someone else, who is the guilty party? But, in the present context, these two perspectives meld into one another. The justified shooter would not be punished by libertarian law, the unjustified one would be. 
A must take place on some territory or other. In the libertarian perspective, all property will be owned privately. So, wherever it occurs, there will be some landowner who can determine who may properly shoot whom.

There are several problems here. Suppose a given landlord has not yet made up any rules to cover this situation. What then? Then, too, it is always possible to ask, private owner $\mathrm{X}$ decided on thus and such rules to cover such situations, but are they just? That is, it is not a logical contradiction to posit a case where a private owner could be mistaken in his judgment on such matters. Another difficulty is that even in a fully free society, it need not be the case that every square inch of land is owned by someone. There is such a thing as abandoned property, or virgin territory that has not yet been homesteaded, or land whose productivity is so low (think tundra) that it will not any time soon be claimed. Suppose this altercation takes place in a venue of this sort. Last but not least, B may grab and then hide behind $\mathrm{C}$ on acreage owned by $\mathrm{X}$, and threaten $\mathrm{A}$, who is now stationed on premises owned by $\mathrm{Y}$. Suppose there is no prior agreement between $\mathrm{X}$ and $\mathrm{Y}$ as to how to handle such a situation. Then again, our deliberations may possibly be of some value.

So, let us move into the breach we introduced at the outset.

We are confronting the question of which of two innocent persons, A and C, may properly shoot the other, the shield, $\mathrm{C}$, and $\mathrm{A}$, the ultimate intended victim of B. It is no use trying to deal with B. He is assumed to be beyond our power, in this example, arguendo.

One option we may rule out of court at the outset is that both A and C may fire at each other, and "let the best man win". There are three problems with this intended solution. First, it is an abnegation of our duty as legal theorists to give up in so unseemly a manner, at least at the outset. Let us surrender, if we need to, only after the (intellectual) battle, but not before.

Second, it offends utilitarian sensibilities. Libertarians are by no means all utilitarians. However, other deontological things being equal, surely we are to prefer a situation where only one innocent person dies, rather than both of them. ${ }^{2}$

Third, when faced with difficult deontological questions of libertarian theory, utilitarianism can sometime rein us in, or serve as a guidepost. For example, any conclusion that results in the death of the entire human race, even minus one, would be looked upon askance by the rational legal theorist. Suppose the B of our example has it within his power to kill off most of the world's population unless he is stopped by A. The only thing holding A back from plugging B is that in order to do so he must shoot right through $\mathrm{C}$, the shield. Even libertarian deontologists with even a hint of utilitarianism in their intellectual armament must start out by favoring A over $\mathrm{C}$ given this scenario. ${ }^{3}$

2 We assume everyone in our tableau is a crack shot, so that pulling the trigger will necessarily result in death. See Block (2011).

3 The present author is mainly a deontologist, but finds utilitarianism sometimes useful. 


\section{Rothbard $(1984,6)$ offers the following analysis:}

Let us now come to the case of the innocent shield which is the most relevant to the problem of war and the State. A, an original victim, is being threatened with assault by criminal B. Let's say that $\mathrm{B}$ is threatening A with a rifle, and he hides behind innocent shield $\mathrm{C}$, who for some reason cannot get out of the way. Does A have the right to shoot in self defense? No, for this makes A the criminal aggressor against $\mathrm{C}$, a fact dramatically revealed by asking the key question: Does $\mathrm{C}$ have the right to shoot A in self-defense? Absolutely. $\mathrm{C}$ is causing no harm, and he (has) the perfect right to defend himself. Shooting the innocent shield is murder, and $\mathrm{C}$ has the right to defend himself with force, and he or his heirs have the right to retaliate. Again our regrets, our "that's the human condition," or "tough cookies" comments must be directed to the criminal A and not to C.

Eric Mack and other political philosophers focus exclusively on A, on his needs and problems: they forget about $\mathrm{C}$, the only person in this tangled triangle who is a pure and undoubted victim and not an aggressor. To borrow a phrase from Sumner, in all this analysis, $\mathrm{C}$, the innocent shield and his rights is the Forgotten Man.

If Professor Mack were to talk about the shield at all, he would admit that the shield has the right to defend himself against $\mathrm{A}$, but then simply say that each person - A or C - has the right to shoot the other. In short, in Mackian emergency situations, rights are in inherent conflict. But this violates the very nature of libertarian natural rights. The whole point of natural rights is that they are eternal and absolute, and that every man's rights are compossible with the rights of every other man. In every situation of a seeming conflict of rights, the libertarian political philosopher must search to eliminate the supposed conflict, and to identify whose rights are to prevail, to find out who is the victim and who is the aggressor. In the case of A aggressing against the innocent shield, it is the shield's rights that are violated, and A who is the murderer. Compossibility is saved.

I like to think of the libertarian political philosopher as a kind of spiritual Lone Ranger, dedicated to defending rights and justice and to combating crime against such against such rights wherever he finds it. Examining all the possible hypotheticals, the Lone Ranger descends from the sky with his six-shooters ablaze, interested in one concern: defense of the victim's rights against aggression. He cares not for excuses, alibis, starvation or emergency situations; he cares only for defense of rights. $H e$ is, in short, the spiritual Defense Agency in an anarcho-capitalist society.

Who, then, would the Libertarian Lone Ranger, the surrogate anarchist Defense Agency, defend - whose side would he take with his six shooters - in all of the above situations? He would unhesitatingly leap to the defense of the storekeeper, the guy on the plank, the Thomson protagonist [...] and, of the innocent shield. He would pop the Mackian victim Mr. A, because he (though unfortunately not Professor Mack) recognizes that taking acting against the shield, the original victim has not become a criminal aggressor and must be gunned down.

We have finished our analysis of Mack's anarcho-warmongering. The innocent bystander is the case most relevant to the question of war and the State. Except that we must postulate a mass of innocent bystanders or shields instead of just one. Ponder this: A is being threatened by B, a sniper, hiding in a crowd of hundreds of innocent people. For various reasons he can't simply leave and he also can't warn the crowd. A must either be shot or else he throws a bomb into the crowd, killing hundreds of bystanders along with the sniper. Is A's action, is mass slaughter of innocents, justified because A's life is at stake? It is hard to believe that any civilized person, much less any libertarian, would justify such an action - not simply because it would be profoundly immoral, but because it commits what for libertarians is the ultimate crime: mass murder. In this case, the Lone Ranger would be happy to pop A before he commits mass murder, and even do it with a Randian 'mocking smile' rather than a sigh of regret. ${ }^{4}$

${ }^{4}$ Nozick $(1974,35)$ also weighs in on this interesting issue, but contents himself with raising a whole host of fascinating questions about it rather than giving any solutions to the challenge. He concludes by writing: "I tiptoe around these incredibly difficult issues here, merely noting that 


\section{Negative homesteading}

Let us now consider a theory on the basis of which we will reach the very opposite conclusion to the one offered by Rothbard. It is called homesteading misery, or negative homesteading. Like its positive counterpart, positive homesteading, the negative variety claims that the first person to encounter an item in nature and mix his labor with it, becomes the owner of it. But there is a large philosophical difference between the two concepts. In traditional homesteading, that which becomes private property is a positive value, a benefit. The first user of land, or the initial person to domesticate an animal, becomes the owner of it. And land, animals, etc., are commonly seen by all as something desirable. In very sharp contrast, negative homesteading involves the ownership, or, perhaps, retention would be a better word, of something that is strictly negative.

For example, consider the lightning rod. Only this one works differently from all the others. It functions not by harmlessly directing the charge into the ground, but rather by diverting it from the first or ostensible victim of the lightning onto the person of another equally innocent individual. Why might this newly-invented imaginary implement be employed? It would be used by the first victim of the lightning, in order to transfer the death producing electrical charge to someone else. $\mathrm{J}$ is about to be struck by lightning. Would it be proper, licit, for him to shift this killing electricity away from him, and onto another person, K? J could in this way save his own life, but only at the cost of killing K. No, says the theory of homesteading bads, or misery: the first victim of the tragedy, lightning in this case, must retain it, may only keep it to himself, may not transfer it to someone else. It would be impermissible for him to shunt it to another equally innocent person. For positive homesteading the motto might well be, "first in time, first in right". In the present case this translates into "first in time, first in wrong" (or bad, or misery).

Let us now return to the previous body-snatching or body shield case. Contrary to Rothbard, we take the side of A, vis a vis $\mathrm{C}$. Where do I claim that this author errs? This author unduly favors $\mathrm{C}$, the shield, and diminishes the rights of A, B's target. One way he does this is by assuming there are thousands of C's around, and only one A. That is, instead of using one man, C, as a shield, Rothbard has B, the baddie, hide himself in a mass of Cs. The baddie is in a residential neighborhood, lobbing bombs at a single A. He asks, would the A be justified in mowing them all down, killing hundreds or thousands of innocent Cs, just to save his own miserable life. Rothbard, perhaps overwhelmed by the utilitarian horror, retreats from, rejects, such a conclusion. But, we could easily turn this around, and tug at the heartstrings from the opposite direction. Now, suppose there to be only one baddie, one innocent shield $\mathrm{C}$, but thousands of victim target As. All of

a view that says it makes non-aggression central must resolve them explicitly at some point". That is precisely the intention of the present paper. 
these thousands of As will die if they, or their guardian, refuses to shoot the single innocent shield, to stop the evil B from killing them all. ${ }^{5}$

No. The proper way to approach this challenge is to apply ceteris paribus conditions. Either there are $1000 \mathrm{Cs}$, but also $1000 \mathrm{As}$, or there is only one of each. Whichever choice we make, it is clear that according to negative homesteading theory, $\mathrm{A}$ is to be preferred to $\mathrm{C}$. That is, it is licit for $\mathrm{A}$ to shoot $\mathrm{C}$ so as to get to B; to stop the baddie B from perpetrating his evil act. Why? Simply because C is the first to homestead misery. B initially grabs up $\mathrm{C}$ as his shield. Only then does $\mathrm{B}$ aim his gun in A's direction, in an attempt to murder him.

Let us now consider a case almost tailor-made to favor A, the innocent target, versus $C$, the innocent shield. Suppose that $B$, the baddie, instead of using $C$ to shield himself, from his intended victim $\mathrm{A}$, instead tosses $\mathrm{C}$ at $\mathrm{A}$. That is, $\mathrm{B}$ utilizes $\mathrm{C}$ as a human missile who he, $\mathrm{B}$, "fires" at $\mathrm{A}$. If and when $\mathrm{C}$ impacts $\mathrm{A}$ (this is assured, B has good aim, is strong and malevolent), both will die. Again, A and C are both entirely innocent of any purposeful initiatory invasive or aggressive behavior. Once more, both $\mathrm{A}$ and $\mathrm{C}$ are armed with pistols, and are crack shots. If $\mathrm{C}$, the human projectile, shoots $\mathrm{A}$, the target of $\mathrm{B}$ the baddie, deadly contact between $\mathrm{A}$ and $\mathrm{C}$ will be avoided, but $\mathrm{A}$ will die of gunshot wounds. On the other hand, if $\mathrm{A}$ the target shoots $\mathrm{C}$, the missile (recently converted from playing the role of shield), then again contact will be avoided, and both need not perish. Here, $\mathrm{C}$ will die and A survive.

In this missile scenario it is perhaps easier to sympathize with $\mathrm{A}$ than in the shield case. $\mathrm{C}$, here, is actively attacking him, A, not of course purposefully, not, merely being used as a passive shield aimed at the same goal of B's, namely, murdering A. But it would be a mistake, I contend, to favor A over C in this missile case, and not in the previous shield scenario. The similarities in their positions, in my view, trump any supposed disanalogies. I ignore the active versus passive elements. To me, it is entirely irrelevant that the shield is passive, while the missile is active. These attributes matter not one whit as far as the results are concerned. In both cases, $\mathrm{C}$ is being used by B to murder $\mathrm{A}$. In both cases, $\mathrm{C}$ is the first to homestead the misery.

Perhaps an analogy may be of help in making this point. Feser (2010) discusses the case where one man, Frank, manages to deprive another man, Pete, of all the air in the environs of the latter, killing him by suffocation. ${ }^{6}$ That would be

5 I refer to this statement of Rothbard's: "we must postulate a mass of innocent bystanders or shields instead of just one. Ponder this: A is being threatened by B, a sniper, hiding in a crowd of hundreds of innocent people. For various reasons he can't simply leave and he also can't warn the crowd. A must either be shot or else he throws a bomb into the crowd, killing hundreds of bystanders along with the sniper. Is A's action, is mass slaughter of innocents, justified because A's life is at stake? It is hard to believe that any civilized person, much less any libertarian, would justify such an action - not simply because it would be profoundly immoral, but because it commits what for libertarians is the ultimate crime: mass murder."

${ }^{6}$ Feser (2010) contends that this does not constitute murder. For an alternative view on this matter, see Block (2010).

Ekonomia - Wroclaw Economic Review 25/1 (2019)

(C) for this edition by CNS 
akin to the passive shield. In both cases, no explicit "invasion" has occurred. In neither case is there an uninvited border crossing, the libertarian litmus test for initiatory violence. But, sucking away someone's air is just as deadly as hiding behind someone else, and using him as a shield. True, the baddie does not directly kill the shield; the target does that. But the baddie bears the ultimate responsibility for that death. In like manner, Peter does not directly kill Frank, either. He does so indirectly. Both the air sucking, and the exposure of the shield to the bullet of the target, end in the same way. Both are efficient means to an end, indeed, the very same end. Why should we be swayed, in our legal analysis, to make any distinction at all between "passive" murder (air sucking, the shield) and active murder (shooting, tossing a human missile against someone)? If there is no difference between these modes of killing, then a gigantic distinction between them cannot be drawn, certainly not one sufficient to convince us to make a 180 degree turn from finding $\mathrm{C}$ at fault (if he shoots $\mathrm{A}$ ) to blaming $\mathrm{A}$ (if he shoots $\mathrm{C}$ ), or vice versa.

Let us consider a series of other cases, the better to put through its paces this theory of negative homesteading we are considering.

The Hulk. A very strong bully boy, think the Hulk, grabs entirely innocent ${ }^{7} \mathrm{X}$ and $\mathrm{Y}$, and is about to bash their heads together, killing both. As it happens, $\mathrm{X}$ and $\mathrm{Y}$ each have a gun, but can only aim at each other, not at the evil Hulk. ${ }^{8}$ If either X or Y shoots the other, the Hulk will release both $\mathrm{X}$ and $\mathrm{Y}$; one will fall down dead, bullet-ridden, the other, the killer, will walk away from this scenario alive. (The Hulk admires those who shoot innocent people).

Ordinary legal theory has no answer to the question of who may legitimately shoot whom, X or Y. Thanks to negative homesteading theory, we at least have something of an answer to this conundrum. And the response is, the one who the Hulk grabbed first must allow the other to gun him down, and may not himself fire at the one who the Hulk grabbed last. Suppose then that the Hulk first seized X. $\mathrm{X}$ is then the first negative homesteader, or the first homesteader of misery. He may not shunt off his negative "property" onto anyone else, such as Y. He has no more right to do this than if, instead of the Hulk grabbing him first, it was lightning that hit him first, and he had the wherewithal, a lightning rod, with which he could transfer the deadly electricity to $\mathrm{Y}$. $\mathrm{X}$ is the first misery homesteader, and must under the libertarian legal code I am now proposing keep it to himself. He may not transfer the lightning to $\mathrm{Y}$, and he cannot properly shoot $\mathrm{Y}$ either, but must suffer the shot of the latter.

What are the alternatives to these conclusions? There are only three. First, we could say that the law cannot and does not give us any guidance whatsoever. But this is an abnegation, a failure of the legal system. ${ }^{9}$ We may well have to reach

7 All victims here are always "entirely innocent".

8 This, too, is a constant refrain in this literature.

${ }^{9}$ Intellectual failures of this sort are not the worst thing in the world. We cannot always achieve pinpoint success. For example, there is no unambiguously correct answer to the question of the age at which statutory rape should kick in. Six years old is way too young for a girl to give con- 
that conclusion, but, not at least without a(n intellectual) fight. Second, we could say, let them both shoot it out, and let the better man, the quicker one with better aim, win. But this is to substitute pistol shooting accuracy for law. It is difficult to see any connection between skill with a gun and justice. Third, we could conclude that neither has a right to plug the other. Both, after all, are innocent, and it is improper to shoot an innocent person, period. The problem here is that if this rule is implemented, both will die, while the logic of the example requires the death of only one of them, at least. This third alternative is akin to saying to two almost drowning men holding onto a plank in the ocean that can support only one of them that both must let go of it. We are now employing the law in an attempt to save one of these victims of the Hulk, not an unreasonable burden to place on the law. We are only tasked with determining which one of them will live. We thus reject alternatives that require the death of both.

But what about the case where the Hulk grabs X and Y simultaneously? Here, by definition, the prior in time, prior in misery rule does not seem to apply. Not so fast. It cannot be denied that time itself, strictly speaking, cannot here be determinative, since we have explicitly ruled it out. But we can resort to a tie-breaking rule in the spirit of negative homesteading. To wit, suppose that the Hulk is right-handed. He can thus exert stronger control over whoever he holds in that particular hand. The justification of this seeming legerdemain is that it is not only the first person to homestead the misery who must keep it, in cases of exact ties in the time dimension we resort to the man who has had greater unhappiness imposed upon him. And, presumably, this means that the victim in the Hulk's right hand can be squeezed more tightly, held more securely.

But suppose that the Hulk is fully, totally and completely ambidextrous. There is not an ounce of difference in strength between his two hands. Well, then, perhaps we can resort to the fact that the Hulk is standing on uneven ground, and that he can thus exert more power with the hand that is lower down, which benefits more from gravity than does the other. Perhaps we can take refuge in pinning the negative homesteading label to whoever he holds in the hand of his closer to the north, ${ }^{10}$ on the ground that this pole exerts more gravitational pull on the Hulk. We admit we are scrambling a bit, here. There is a precedent for this sort of thing. In baseball, a tie between the runner and the ball at first base goes to the runner. This, too, is a bit arbitrary. To repeat: what justifies this mad dash after tie-breakers is the desire to save one victim's life, and to render law more all inclusive. It is our only compass. What else are we to use to analyze such situations?

sent to sexual intercourse, and 26 is way too old to deny this choice to a woman. What is the right age? Is it $15,16,17,18$ ? Somewhere in that range, most likely. But the difficulty is that no matter what age is picked, there will be females who are younger than that cut off who are more mature than someone older than she.

10 Assuming that this little tableau takes place in the northern hemisphere. 
Next case. The Hulk grabs C and D and places them in a colosseum. He tells them to fight it out between themselves for their lives. The winner will be freed. If both refuse to fight, then both die (the tigers are released). Now, under ordinary circumstances, either the law has no answer, or they are both consigned to death. This is so since it is a basic axiom law, at least libertarian law, that no one may launch an aggressive attack on any innocent person, such as these two, $\mathrm{C}$ and $\mathrm{D}$. But, fortunately in this otherwise very, very dire case, negative homesteading offers (admittedly a very second best) another option. If the Hulk grabbed $\mathrm{C}$ before $\mathrm{D}$, or if he was let into the arena before his opponent, or if one is facing the sun (and thus is at a disadvantage) and the other not, or if one is placed on higher ground than the other, a modicum of legal rationality, and one life, may be seized from this morass. Note, we do not enquire as to whether C or D is younger, faster, stronger or a better fighter than the other. We do not "ask" the weaker or older one to give in without a struggle. Why not? Although these considerations might serve on other grounds (e.g., utilitarianism, by requiring that the older or feebler one be killed), they have nothing to do with negative homesteading, our litmus test in these cases.

Yet another case. Here, the Hulk threatens $\mathrm{X}$ that unless he murders $\mathrm{Y}$, the Hulk will murder $X$. It is still impermissible for $X$ to do any such thing, even to save his own life. ${ }^{11}$ Negative homesteading theory supports this conclusion: $\mathrm{X}$ was the first to be immiserated, not $\mathrm{Y}$. Does the issue change if the threat the Hulk holds over $\mathrm{X}$ is that unless he murders Y, X's child will be killed? Here again, the theory of homesteading misery is clear. X may not do any such thing, and if he does, he would have to be punished to the full extent of the law. For $\mathrm{X}$ is the first homesteader of the Hulk's wrath, and must keep it to himself. He may not, he cannot be allowed by law, to shift this unhappiness onto equally innocent Y.

Another case. A comet is about to impact the Earth. If it hits, all of humankind will perish. Fortunately, Bruce Willis and the boys ${ }^{12}$ are on the job. They can blast this heavenly body out of the sky, pulverizing it, and saving mother Earth ${ }^{13}$ and all of her inhabitants. Unfortunately, our would-be heroes are all libertarians, guided by the non-aggression axiom, and there happens to be an innocent person who lives on that meteor. If we blow it up, this man will die. No. This is too easy a case. This inhabitant of that rock will perish in any case when his home crashes into the Earth. It is too easy to justify Bruce killing him. Let us assume, instead, that this innocent person is in a small spaceship, merely closely accompanying the comet. If we blow

11 Why does not the Hulk just murder $\mathrm{Y}$ himself, rather than going through $\mathrm{X}$ as an intermediary? There are several options. The Hulk is lazy. The Hulk is considerate of us, and wishes to furnish us with an example. The Hulk is a sadist, in the case of threatening X's child.

12 Armageddon; http://www.imdb.com/title/tt0120591/ (retrieved January 10, 2017).

13 In all the present furor over the global warming, very few have noted that this sort of threat may well require more high technical skills, with accompanying industry and perhaps more global warming. 
up this asteroid, he is so close that he will die. If we do not, it will impact the Earth, killing all of the human race except him. He has enough food, water, oxygen, to continue poking around the universe for the rest of his life. Right before the crash of the two bodies, he will fly away to Mars, or some such place. Radio contact has been broken off, we cannot warn him away from his present itinerary.

At first blush it would appear that the negative homesteading theory breaks down. That is, it gives an answer incompatible with utilitarian considerations (saving the Earth). For our lone space explorer is as innocent as any other of the characters we have so far considered, nor has he been "grabbed up" by any aggressor such as our friend the Hulk. Instead, it is we on Earth who are the negative homesteaders. The comet is threatening us, not him. He is merely in the neighborhood of this danger to the Earth.

If he were but dependent in some way on the meteor, then we could blast it and him along with it, in good conscience, at least insofar as homesteading misery is concerned. Did he but play the role of the bird who accompanies the hippopotamus, ${ }^{14}$ or the fish to the shark, ${ }^{15}$ we could so do, not on the ground, however, of negative homesteading, but rather, since our space wayfarer, like these animals, was playing the role of aider and abetter of a rights violator. The bird and the fish, respectively, have a symbiotic relationship with their hosts, the hippo and the shark. In return for protection and food, they clean and groom their symbiotic partners.

But this conclusion, as I say, is reachable only as a first approximation. Upon further analysis, we can make a case that the theory of negative homesteading can withstand this critique. For, if the spaceship operator follows the comet so close to its ultimate destination with the Earth that the former cannot no longer be blown up in such a way as to save the latter, he is acting, how shall we say this charitably inconsiderately. He is at the very least acting as if he is in thrall to this demon-like planetoid that is about to unleash such devastation onto the Earth. It is as if this meteor is exerting a baleful influence on him, as if he has been placed under the power of a malevolent heavenly body. As if, that is, he has first bee $n$ captured by the asteroid, with the express purpose of keeping this astronaut precisely in its neighborhood, so that the earthlings, under the guidance of Bruce Willis, cannot shoot it out of the sky. Where have we come upon such a situation? It is as if this planetoid is using the astronaut as a $\mathrm{shield}$ to prevent its intended victims, the inhabitants of the third planet, from firing back at it. The situations are exactly parallel. Only the baddie is now the asteroid, the victims are the earthlings, and the shield is the astronaut.

At last we arrive at the Martian case, the mother of them all, in this genre. The inhabitants of that planet beam down a message to us earthlings that unless one of

$14 \mathrm{http} / /$ www.google.ca/search?hl=en\&q=symbiosis+hippo+bird\&btnG=Google+Search\&m eta $=($ retrieved January 10, 2017).

$15 \mathrm{http}: / /$ www.google.ca/search?hl=en\&q=symbiosis + shark + fish \&btnG=Google+Search\&m eta $=($ retrieved January 10, 2017). 
us kills innocent person Joe, they will blow up our entire planet. ${ }^{16}$ We can imagine them, clever species that they are, adding an addendum to their threat that if no one kills Joe, they will save him, as they blow us up. Otherwise, this example would be too simple; we might think that as Joe is a goner in any case, we can kill him with impunity. If we refrain, he will die as the Earth ends no matter what we do.

One might think that according to negative homesteading theory, we may not legally comply with the Martian demand. For it is we all who are first visited with the misery. But this is not the case. The threat is made, first, against all of the people of the Earth. This is identical to the case where the Hulk demands that $\mathrm{X}$ kill $\mathrm{Y}$, under grievous threat to $\mathrm{X}$.

An easy way out of this conundrum is for some hero to go and kill Joe, and then present himself for the capital punishment libertarian law would require in such a circumstance. Then, we could have our cake and eat it: save the Earth without violating the non-aggression axiom of this philosophy. After we hold a ticker-tape parade for this individual, we execute him. But the Martians are too smart for us. They say that if we punish the murderer of Joe, they will blow up the world. They could in this way still drive a wedge between libertarian justice and (gross) utilitarianism (saving humanity).

There are two problems with the Martian case. One, it shows just how far we have to go to drive a wedge between libertarianism and gross utilitarianism (saving humanity). Two, it violates our ceteris paribus strictures. It places its thumb on the scales of justice by weighting one side with the entire world's population, and lightens the other side by placing only Joe on it. The problem here is that the numbers are unbalanced. This is the same criticism we made of Rothbard, see note 4 supra. Suppose that the Martians change the message they beam down to us earthlings. They tell one single individual, our man Joe, that unless he, alone, kills off the entire Earth's population, they, the Martians, will kill Joe only. Is there anyone amongst us who now thinks we should lie idly by while Joe kills us all in order to save his own life? I venture to say this would not be a widely popular notion amongst the world's peoples. ${ }^{17}$

\section{Commentary}

Having introduced negative homesteading theory, and illustrated with a series of cases, we now move on to the next phase of this paper, applying it, comparing it,

16 Heinlein, 1961, flirts with this theme. We assume away, arguendo, the possibility that the Martians just have this one ax to grind, with this one poor fellow-human named Joe. In other words, if we cooperate in this case, we would just open the box for endless similar demands. (I owe this point to Guido Hulsmann).

17 We do indeed have widely disparate views on U.S. imperialism, the Kyoto accord, communism, capitalism, Saddam Hussein, Machmoud Ahmadinejad, and many other topics. But, on this one, I feel it is safe to say, virtual unanimity would easily be attained. 
contrasting it, to the theories offered by several others who have examined these sorts of shield and human missile problems. First in the batter's box in this regard is Thomson (1991).

She starts off with a series of cases where people are under attack, and may or may not kill in self-defense. Villain Aggressor is purposefully chasing you around with a truck, trying to run you down and kill you. Innocent Aggressor is doing precisely the same thing, but not purposefully; he is acting in this manner because he has been forcibly drugged. This author supports you in blowing away both of these aggressors with your handy anti-tank gun, a stance totally consistent with libertarianism. Thomson $(1991,285)$ then states: "while it is permissible for you to proceed in Villainous Aggressor, it is merely excusable [...] in Innocent Aggressor". This is a bit too finely detailed for libertarian analysis, which asks only one question: is the person who pulverizes the attacking truck guilty of a crime or not?

However, in the course of her discussion of these two cases she asks (1991, 285): "But who are you, private person that you are to be dishing out punishment to the villainous for the things that they do?" This is a problem for libertarianism, for in this philosophy, there are on $1 \mathrm{y}$ "private persons" as far as the law is concerned. No one who enters government service obtains any new powers that he did not have beforehand, as a private person. A democratic vote would certainly not garner for anyone such legitimacy. Hitler, after all, came to power through democratic institutions. If two burglars break into your home and outvote you as to whether they can abscond with your TV set, this certainly does not justify their depredation.

Another difficulty libertarians have with Thomson $(1991,286)$ arises with her contention that "If the aggressor would [...] take your wallet or hat, then you may not kill the aggressor to defend yourself [...] you may kill him to defend your left foot against his aggression if he is at fault but not if he is without fault. I leave this open".

Open? I don't know about you, but I've only got two feet. Maybe, if I had three, I might take a different perspective on this question, although even then I seriously doubt it. The thought of standing idly by, and consenting to the loss of one of my precious feet, when I have the alternative of blasting away at, and killing, the "without fault" malefactor who had bad intentions with regard to one of my appendages, is nothing short of appalling. When it is my foot against his entire body, I know in which libertarian law points. There is an entire body of libertarian and even non-libertarian law which would allow, nay, support, a person defending himself against an aggressor who aims to cut off his foot, whether this attacker has mens rea or not. But the same goes for the wallet or hat, if that is the only way to stop the theft.

In Thomson's (1991, 287; words in brackets inserted by present author) Innocent Threat: "A villain [...] pushes [...] (a) fat man off the cliff (above you) down toward you. If you do nothing, the fat man will fall on you and be safe. But he is very fat, so if he falls on you he will squash you and thereby kill you". This is the case we have dealt with supra under the heading of "human missile". Her $(1991,287)$ answer is that yes, you may kill to defend your life in this case, since, 
"although without fault", the fat man is "aggressing against you". She reaches this result in all three cases, because $(1991,288)$ "the man you kill if you proceed will otherwise kill you". Together, the Violent Aggressor, the Innocent Aggressor, and the Innocent Threat, constitute her three "Yes cases". So far, so good; Thomson's results are identical to that reached through libertarianism and negative homesteading theory albeit for different reasons.

Next, this author moves on to several No cases, where you are not permitted to kill someone, even to save your own life. First considered are Substitution-of-a-Bystander cases. One subset is Trolley, where this vehicle is bearing down on you and will surely kill you, unless you deflect it onto a bystander who cannot evade it. Thomson (1991, 289-290) reaches the correct libertarian conclusion, although her reasoning is somewhat unclear: "I take it to be plain that you may not proceed. If you proceed, you will be making a bystander a substitute victim". But what is wrong with that, we are not told. Negative homesteading is clear on this matter. Just as in the lightning case, where the first homesteader of the misery must retain it, the first victim of the trolley must bear the unhappiness, and may not shift it onto the bystander. Second in this category is Use-of-a-Bystander. Here, you can shoot a bystander who will then fall on the trolley, stopping it. Again, she reaches the libertarian conclusion $(1991,290)$ : "it is plain that you may not proceed. To proceed would be to use a bystander as a piece of equipment" but it is not crystal clear as to why you may not do this. Why not use people as pieces of equipment? In contrast, negative homesteading maintains that you are the first victim of the trolley, and must keep its deleterious effects to yourself. The libertarian proscription against aggression against non-aggressors would also cover this matter. ${ }^{18}$

Third is Riding-Roughshod-over-a-Bystander. In this instance, someone is shooting at you. You can escape, but only by toppling someone off a bridge to his death. Thomson $(1991,290)$ takes the view that "it is plain that you may not proceed". Here, again, the views of this author overlap with the vision of libertarianism offered at present. ${ }^{19}$

\section{Conclusion}

I conclude that negative homesteading can shed light on several challenges to libertarian theory. On occasion, this concept leads us in different directions than other libertarian commentators have claimed, to say nothing of non-libertarian scholars. Negative homesteading is unexpectedly quite a clean solution to the trolley issue, amongst others.

18 In her (Thomson, 1991, 290) view, the shield case is a combination of the Substitution-ofa-Bystander and Use-of-a-Bystander cases.

19 Other "mainstream" authors who have analyzed similar situations include Clark, 2000; Otsuka, 1994, 2003; Statman, 2006; Wasserman, 1987; Di Nucci, 2013; Liao, et. al, 2012; Kahane, 2015; Sinhababu, 2014; Edmonds, 2014. See also Thomson, 1985. 


\section{References}

Alexander, L. (1993). Self-defense, justification, and excuse. Philosophy and Public Affairs, 22(1), 53-66.

Block, W. E. (2010). Libertarianism is unique; it belongs neither to the right nor the left: A critique of the views of Long, Holcombe, and Baden on the left, Hoppe, Feser and Paul on the right. Journal of Libertarian Studies, 22, 127-70. Retrieved January 10, 2017 from http://mises.org/ journals/j1s/22_1/22_1_8.pdf.

Block, W. E. (2011). The human body shield. Journal of Libertarian Studies, 22, 625-630. Retrieved January 10, 2017 from http://mises.org/journals/jls/22_1/22_1_30.pdf.

Clark, M. (2000). Self-defense against the innocent. Journal of Applied Philosophy, 17(2), 145-155.

Di Nucci, E. (2013). Self-sacrifice and the trolley problem. Philosophical Psychology, 26, 662-672. Retrieved January 10, 2017 from http://www.tandfonline.com/doi/full/10.1080/09515089.201 2.674664 scroll $=$ top \&needAccess $=$ true.

Diamond, A. M. (1980). F. A. Hayek on constructivism and ethics. Journal of Libertarian Studies, 4(4), 353-366. Retrieved January 10, 2017 from http://mises.org/journals/jls/4_4/4_4_2.pdf.

Edmonds, D. (2014). Would You Kill the Fat Man? The Trolley Problem and What Your Answer Tells Us About Right and Wrong. Princeton: Princeton University Press.

Feser, E. (2010). Reply to Block on libertarianism is unique. Journal of Libertarian Studies, 22, 261-272. Retrieved January 10, 2017 from http://mises.org/journals/jls/22_1/22_1_13.pdf.

Hayek, F. A. (1973-1979). Law, Legislation and Liberty, 3 vols. Chicago: University of Chicago Press.

Heinlein, R. (1961). Stranger in a Strange Land. New York, NY: Putnam.

Kahane, G. (2015). Sidetracked by trolleys: Why sacrificial moral dilemmas tell us little (or nothing) about utilitarian judgment. Social Neuroscience, 10(5), 551-560. Retrieved January 10, 2017 from http://www.tandfonline.com/doi/full/10.1080/17470919.2015.1023400?src=recsys.

Liao, M, Wiegmann, A., Alexander, J., Vong, G. (2012). Putting the trolley in order: Experimental philosophy and the loop case. Philosophical Psychology, 25(5), 661-671. Retrieved January 10, 2017 from http://www.tandfonline.com/doi/full/10.1080/09515089.2011.627536?src=recsys.

Nozick, R. (1974). Anarchy, State and Utopia. New York: Basic Books.

Otsuka, M. (1994). Killing the innocent in self-defense. Philosophy and Public Affairs, 23(1), 74-94.

Otsuka, M. (2003). Killing the innocent in self-defense. In M. Otsuka, Libertarianism Without Inequality (66-85). Oxford: Oxford University Press.

Rothbard, M. N. (1984). Eric Mack and the anarchist case for war. Libertarian Forum, 18(5-6), 3-7.

Sinhababu, N. (2014). Review of Would You Kill the Fat Man? The Trolley Problem and What Your Answer Tells Us About Right and Wrong by David Edmonds. Australasian Journal of Philosophy, 92(4), 818-819.

Statman, D. (2006). Supreme emergencies revisited. Ethics, 117, 58-79.

Thomson, J. J. (1985). The trolley problem. The Yale Law Journal, 94(6), 1395-1415.

Thomson, J. J. (1991). Self-defense. Philosophy and Public Affairs, 20, 283-310.

Wasserman, D. (1987). Justifying self-defense. Philosophy and Public Affairs, 16(4), 356-378. 